\section{J.Thi-Qar Sci.}

ISSN 1991- 8690

Website: http://jsci.utq.edu.iq

No. (3)

Vol.1

Janu. /2009

الترقيم الدولي . 1991 -

Email:utjsci@utq.edu.iq

Spread of Giardiasis Among Children In Al-Nassiria city southern

Iraq

Talib Falih Hassen

Medical department- Nassiria Technical Institute -Thi_Qar - Iraq

\title{
Summary
}

Over -12 month period from January 2006 to December 2006 , 898 cases of Giardiasis were diagnosed in Al-Nassiria citySouthern Iraq . The age of subject ranged from below one year to ten years. The prevalence rate of giardiasis among male significantly higher than among female $(55.1 \%)$ and $(44.9 \%)$ respectively . The high rate of infection with Giardia lamblia $125(93.3 \%)$ cases in children (1-2) years old, Also result revealed that the cyst phase was dominant $(61.6 \%)$ than trophozoite $(38.3 \%)$. Mixed infections showed double infections with Giardia lamblia 56(62.3\%).The common symptoms was diarrhoea $(\mathbf{9 4 . 1 \% )}$ ) and the highest rate of infection were in summers months . 


\section{Introduction}

Giardia Lamblia is an intestinal parasite and worldwide distribution among population especially children and found to be common cause of abdominal pain and diarrhea [1,2 , 3] Giardia Lamblia only in more recent years has it become recognized as a very common pathogen [4]. Giardiasis is a common intestinal infection spread by eating contaminated food, drinking contaminated water, or through direct contact with the organism that causes the disease [ 5,6 ]. It occurs more frequently in children than in adults [ 7 ].Many prospective studies have reported that the prevalence of parasitic infection in children under ten years of age was higher than for all other age group [ 8,9 ] . Giardia Lamblia exists in two forms, the trophozoite has been likened in shape to badminton racket it has asucking disc on ventral surface which enables it to adhere to intestinal epithelium [4]. The aim of this study to determine the prevalence rate of giardiasis among children, males and females of various socio-economic levels in AlNassiria city- Southern Iraq.

\section{Materials and methods}

The Pediatric patients were included in this study they were admitted to Paediatric hospital in Al-Nassiria city- Southern Iraq from January 2006 December 2006 .The age of subjects are ranging from below one year to ten years . 2100 samples of stool were collected in clean screw capped containers. The stool samples were examined with the naked eye for color, consistency and the presence of any adult helminthes the stool samples were examined at the same day by direct method microscopically using $0.85 \%$ saline and lugols iodine solution to determine the parasite .[10]

\section{Results}

Out of (2100) sampled examined . $898(42.7 \%)$ were positive for giardiasis and the total percent of infection, sex and age distribution are shown in tabl(1). According to the sex , majority were male 494 (55\%) while female 404 (44.9\%) . as it is shown in table (1), children between $1-2$ years old are the predominantly infected group ,125 (93.3\%), while the lowest affected group was $5-6$ years old , 50 (20.5\%). 


\section{J.Thi-Qar Sci. No. (3)}

Vol.1

Janu. /2009

Table (1) : Infection percentage of Giardiasis among different age groups

\begin{tabular}{|c|c|c|c|c|c|c|c|c|c|}
\hline \multirow{2}{*}{ Age (year) } & \multicolumn{3}{|c|}{ No .o samples } & \multicolumn{3}{c|}{ No. of positive } & \multicolumn{3}{c|}{ Positive percentage } \\
\cline { 2 - 10 } & Male & Female & Total & Male & Female & Total & Male & Female & Total \\
\hline $\begin{array}{c}\text { Below one } \\
\text { year }\end{array}$ & 69 & 65 & 134 & 30 & 21 & 51 & 58.8 & 41.1 & 38 \\
\hline $1-2$ & 70 & 63 & 133 & 73 & 52 & 125 & 58.4 & 41.6 & 93.3 \\
\hline $2-3$ & 203 & 122 & 325 & 50 & 61 & 111 & 45 & 54.9 & 34.1 \\
\hline $3-4$ & 180 & 197 & 377 & 57 & 53 & 115 & 51.8 & 48.1 & 29.1 \\
\hline $4-5$ & 193 & 60 & 253 & 80 & 34 & 114 & 70.11 & 29.8 & 45 \\
\hline $5-6$ & 90 & 153 & 243 & 27 & 23 & 50 & 54 & 46 & 20.5 \\
\hline $6-7$ & 53 & 64 & 117 & 36 & 44 & 80 & 45 & 55 & 68.3 \\
\hline $7-8$ & 80 & 112 & 192 & 52 & 46 & 98 & 53.1 & 46.9 & 51 \\
\hline $8-9$ & 103 & 74 & 177 & 64 & 36 & 100 & 64 & 36 & 56.4 \\
\hline $9-10$ & 86 & 63 & 149 & 25 & 34 & 59 & 42.3 & 57.6 & 39.5 \\
\hline Total & 1127 & 973 & 2100 & 494 & 404 & 898 & 55 & 44.9 & 42.7 \\
\hline
\end{tabular}

Also result revealed that the cyst phase are dominant 554 (61.6\%) than trophozoite 344 $(38.3 \%)$, table $(2)$.

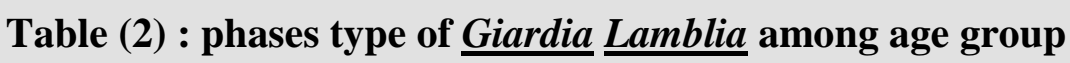

\begin{tabular}{|c|c|c|c|}
\hline Age (year) & Cyst & trophozoite & Total \\
\hline Below one year & 25 & 26 & 51 \\
\hline$r-1$ & 83 & 42 & 125 \\
\hline$r-r$ & 64 & 47 & 111 \\
\hline$\pm-r$ & 96 & 14 & 110 \\
\hline $0- \pm$ & 61 & 53 & 114 \\
\hline $7-0$ & 28 & 22 & 50 \\
\hline$v-r$ & 53 & 27 & $\mathbf{8 0}$ \\
\hline$\wedge-v$ & 50 & 48 & 98 \\
\hline $9-\wedge$ & 63 & 37 & 100 \\
\hline $1+-9$ & 31 & 28 & 59 \\
\hline Total & $554(61.6 \%)$ & $344(38.3 \%)$ & $898(100 \%)$ \\
\hline
\end{tabular}


56 out of 898 infected samples showed double infections with other intestinal parasites combined with Giardia lamblia (Table 3).

Table(3) :Mixed infection among children

\begin{tabular}{|c|c|c|}
\hline Mixed infection & $\begin{array}{c}\text { No. Of samples } \\
\text { infected }\end{array}$ & $\%$ positive \\
\hline G.lamblia + Entomoeba histolytica & 23 & 41.0 \\
\hline G.lamblia + Hymenolypis nana & 16 & 28.5 \\
\hline G.Lamblia + Entomoebacali & 13 & 23.2 \\
\hline G.lamblia + Blastacystis hominis & 4 & 7.1 \\
\hline total & 56 & 100 \\
\hline
\end{tabular}

Table (4) showed the main symptoms is diarrhoea $846(94.1 \%)$. On the other hand table (5) showed that the incidence of Giardiasis were highest in summer months when comparision with other months such as winter months .

\section{Table (4) : Clinical manifestation of childhood Giardiasis}

\begin{tabular}{|c|c|c|}
\hline Symptoms & No. of positive cases & $(\%)$ \\
\hline Diamhoea & $\mathbf{8 4 6}$ & $\mathbf{9 4 . 1}$ \\
\hline Abdominal & 793 & $\mathbf{8 8 . 2}$ \\
\hline Distension & 476 & 52.3 \\
\hline Vomiting & 412 & 45.8 \\
\hline
\end{tabular}




\section{Table (5) : Incidence of Giardia Lamblia infection a according to months of vear}

\begin{tabular}{|c|c|c|}
\hline Months & No. of positive cases & Positive percentage \\
\hline January & 25 & $(2.7)$ \\
\hline February & 31 & $(3.4)$ \\
\hline March & 14 & $(1.5)$ \\
\hline April & 51 & $(5.6)$ \\
\hline May & 135 & $(15)$ \\
\hline June & 114 & $(12.6)$ \\
\hline July & 169 & $(18.8)$ \\
\hline August & 130 & $(14.4)$ \\
\hline September & 98 & $(10.9)$ \\
\hline October & 101 & $(11.2)$ \\
\hline November & 14 & $(1.5)$ \\
\hline December & 16 & $(1.6)$ \\
\hline Total & $\mathbf{8 9 8}$ & $\mathbf{1 0 0 \%}$ \\
\hline
\end{tabular}

\section{Discussion}

This is the first epidemiological study on Giardia lamblia(Giardiasis) infection in AlNassiria city- Southern Iraq . Giardiasis disease are amajor problem in Iraq as in other developing countries [ 11,12 ].

It is the most common cause of parasitic gastrointestinal diseases [13 ]. Infection with Giardia Lamblia is common among children [4] and in this study indicated that $42.7 \%$ of the children were infected with Giardiasis, this finding is in agreement with those report by $[4,8,14]$. The rate of infection in the present study is similar to other studies in Iraq $[15,16,17,18,19]$, many reports showed that the Giardia Lamblia infection is the most common observed pathogenic protozoal parasite among studied group [16,17] and this results may be due to distribution of Giardiasis among children with low socioeconomic levels ( poor families ) with poor hygiene are excellent targits for oral fecal transmission and might be related to bad personal hygiene or overcrowding [ 14 ] .This high rate of infection among children could be related to a number of factors such as poor health hygiene and toilet training, overcrowding, low education of children [ 14 ]. Giardiasis occurs in all ages but is most common in early childhood. The high rate of infection with Giardia Lamblia_in children (1-2) years and this result go with simillar report [ 20 ]. Males have been noted to be at higher risk for infection than females this result go with[21,22] .The cyst phase of Giardia Lamblia_was predominant in this study and this findings is similar to many studies [4,21,23], The trophozoite can be seen in 
duodenal aspirates,but rarely in the faeces and in its passage through the colon the parasite becomes encysted [24]. The present study revealed that the intestinal parasites Entamoeba histolytica and $H$. nana was the most common intestinal parasite associated with Giardia lamblia infection (mixed infection). Although other studies have demonstrated the same results [ 25,26$]$, there was no clear reason for this mixed infection.The incubation period is at least one week, usually longer and the main symptoms is diarrhoea and this may be mild three or four stools aday this finding by [4] and our result it is similar to that findings. The child may have no acute diarrhoea but passes large bulky stools [4] a significant seasonal variation was observed, with a peak in late summer to early fall, which correlates with the pattern found in the many studies[ 26 ,27], and this might be due to ingestion of cyst in contaminated food or drink . This study suggests that Giardia Lamblia is the most important parasitic pathogens among paediatric diarrhoea cases.

\section{References}

1. Abdel - Hafez ,S,k and Abdel - Hafez ,Y.M. (1984).: Human intestinal parasites in the Jordan valley . Apreliminary report .j. Bio. Sci . Res . 15 : $43-53$.

2. $\mathrm{Abu}-\mathrm{AL}$ - saud, A.S. (1983) : Faecal parasites immon - saudi cateing and demostic staff at the riyadh military Hospital, saudi Med .J 4(4) : 259 .

3.. Kadir, M.A., , (1993) :Survey study of intestinal parasites in Kirkuk paediatric hospital . J. Fac . Med . Baghdad). 35, (3) : $315-320$.

4. christie , A.B.(1980) : Gardiasis Epidemiology, pathology and treatment . post graduate doctor J. 3 (6) : $216-220$.

5. Ang LH. (2000): Outbreak of giardiasis in a daycare nursery. Commun Dis. Public Health. ;3:212-3.

6. Hadjichristodoulou C, Achileas G, Yianis P, Yianis T.( 1998): Outbreak of giardiasis among English tourists in Crete. Lancet.;351:65-6.

7. Al-Saeed A.T and. Issa S.H. ( 2006 ) : Frequency of Giardia lamblia among children in Dohuk, northern Iraq (WHO) 12 (5) September

8. Annotation. (1974) : Gardiasis from Russia . Br.Med .J.2 : 394.

9. Mahdi ,N.K. and Jassim,A.H. (1987) : Intestinal parasitic intection of primary school children in three regions of south iraq. Med. J. Basrah unv . 6(1): 55 .

10. Cheesbrough M, (1998); District laboratory practice in tropicacountries.Part1. Cambridge, Cambridge University Press,:192-205.

11. Shakkoury WA and Wandy E A. (2005) : Prevalence of Giardia lamblia infection in Amman ,Jordan Pak J Med Sci April- June 21 ( 2): 199-201. 
12. Sneyd E, Lopez L, Eglinton M,( 2002): Annual Surveillance Summary 2001. Wellington: Institute of Environmental Science and Research Limited (ESR);.

13. Anonymous.( 2000) Giardiasis in England and Wales. Commun Dis Rep CDR Wkly. ;10:325.

14. Hellard M.E.(2000) : Prevalence of enteric pathogens among community based asymptomatic individuals. Journal of gastroenterol and hepatol, , 15(3):290 - 3.

15. Al-Dabagh MA.(1967);Giardiasis in a group of preschool age children in Iraq. Journal of the Faculty of Medicine Baghdad, , 9:73-83.

16. Mahdi N.K, Jassim A.H.( 1987): Intestinal parasitic infections of primary school children in three regions of southern Iraq. Medical journal of Basra University, , 6:55-61.7.

17. Al- Rahaley IMK. Some aspects of enteropathogenic Escherichia coli from diarrheic children in hospitals andnormal children in nurseries [MSc thesis]. Mosul, Iraq, University of Mosul, 1988.

18. AL -Abaidy, N.A .(1988) : The correlation of Helminthic ova and protozoa cyst in human and in dust avound hourses in some villages around Mosul . Msc . thesis submilted to mosul Univ. p. 60 .

19. Molan AL, Farag AM. (1989):Prevalence of intestinal parasites in school children of Erbil, Northern Iraq. Saudi medical journal, , 10:107-10.

20. Black , R.E; Dykes ,A.C. and sinclair , S.P.(1977) : Gardiasis in day - care centers : evidence of person to person trans mission paediatr . $60: 486$.

21. Khan ,M.V; Amir ,S.E. and Aggrewal, S. (1989) : prevalence of intestinal parasites among patients in the abha region. Annais of saudi Medicine . $9(5): 471-474$.

22. AL-Fayez ,S.F. and khogheer, Y.A. (1988) : Afollow - upstudy on prevalence of parasitic infection among patients attending king Abdulaziz University hospital . Jeddah . saud . Medical J. 10 (3) : $193-197$.

23. Kadir , M.A.; Kadir , A.A. and farag , K.K.(1987): Survey of the intestinal parasites among different population of Arbil city . J. Fac . Med . Baghdad . 29(4) : 45 .

\section{WWW.Giardia lamblia, more information,Answer .com}

25. Craun G.F.: Waterborne giardiasis in the United States: a review. American journal of public health, 1979, 69:817-9.

26. Farthing M.J.( 1994): Giardiasis as a disease. In: Thompson RCA, Reynoldson JA, Lymbery AJ, eds. Giardia: from molecules to disease and beyond. Wallingford, CAB International,:15-57.

27. Paniker,C.K. (2002):Textbook of parasitology, 5 ed, Jaypee Company, ,34- 39 


\section{$\begin{array}{llll}\text { J.Thi-Qar Sci. No. (3) } & \text { Vol.1 Janu. /2009 }\end{array}$}

$$
\begin{aligned}
& \text { انـتشـار مـرض الـجيـارديـا بـــن الاطفـال فـي مـديـنـة الـنـاصريـة } \\
& \text { جـنـوب الـعـر اق } \\
& \text { طـالـب فـالـح حسن } \\
& \text { قـسم الـتمـريـض - الـمـعهـد الـفـنى - نـاصريـة }
\end{aligned}
$$

الـخلاصه

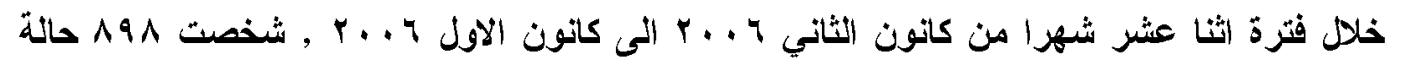
اصابه بالجيارديا عند الاطفال في مدينة الناصرية جنوب العزاق و كان اعمار الاطفال المصابين تثراوح من اقل من سنه الى عثرة سنوات .و كانت نسبة الاصابه في الذكور 1\%00, اعلى مما هو عليه عند الاناث 9, ؛ ؛ \% و اوضحت اللراسة ان اعلى نسبه للاصابه كانت عند الاطفال بعمر 1 - r سنه ووجد ايضا ان الطور المتكيس للطفيلي المسبب للمرض هو السائد 7, 17\% . اوضحت الدراسة ايضا ان هنالتك

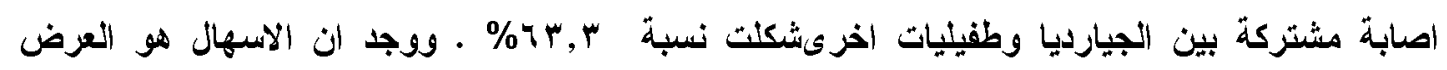
المرضي السائد عن بقية اعر اض والعلامات المرضية|ذ شكل مانسبته ار ؟ 9\% . و لوحظ كذلك ان اعلى نسبه للاصابه كاتت في اشهر الصيف والخريف عند المقارنة بيقية اشهر السنة . 